\title{
The Shift to Online Classes During the Covid-19 Pandemic: Benefits, Challenges, and Required Improvements from the Students' Perspective
}

\author{
Dan Li \\ Hunan Railway Professional Technology College, Zhuzhou City, China \\ womaggielee@hotmail.com
}

\begin{abstract}
The Covid-19 pandemic has radically changed and disrupted education; colleges and universities have closed their campuses, and many have shifted to online courses. In the pre-pandemic era, online classes were associated with several benefits and challenges, and the pandemic might have brought additional benefits and obstacles. This research examined students' perceptions of online classes during the pandemic. The study looked at four aspects: perceived benefits of online classes; perceived challenges; beliefs and an overall evaluation; and potential improvements. An online questionnaire was administrated to some first- and second-year undergraduate students at a College in China. It combined a set of 23 closedended and open-ended questions and 342 valid and complete responses were collected. Perceived benefits included creating a digital learning community, improving students' digital learning skills, and staying connected during tough times. Challenges comprised adaptability issues due to the sudden shift to online classes, time-management issues, being distracted by social media plus technological obstacles. Regarding beliefs, students believed that a blended model that combines both classroom and online modes is necessary for the post-pandemic era. To enhance the sustainability of online classes in the postpandemic era, a set of improvements are explored and suggested.
\end{abstract}

Keywords: Online classes; shift; education during pandemic; Covid-19 impact on students; sustainability of online learning; students' perceptions, blended-learning

\section{Introduction}

\subsection{Overview}

The Covid-19 pandemic has dramatically changed - and disrupted - education as we know it; academic institutions have been shut all over the world. In an attempt to curb the spread of the virus, governments have temporarily closed schools, colleges and university campuses, affecting more than $60 \%$ of the student population globally (UNESCO, 2020). In the wake of the pandemic, universities around the world have adopted a wide range of tactics like switching some courses online, delaying the starting dates of some programs, extending intake application deadlines, and deferring some unconditional offers of 2020 to the following years (QS, 2020).

The disruption caused by Covid-19 has pushed academic institutions to focus their efforts on facilitating a swift, rapid, and unexpected transition to online education and assessment (Jack and Smyth, 2020). The result of these efforts is a substantive rise in e-learning, whereby teaching and learning activities are taking place remotely via digital platforms. In an ongoing survey conducted by QS Top Universities Ranking, almost half of the participating universities stated that they have switched some of their scheduled courses online, and the trend is expected only to grow (QS, 2020).

On the $4^{\text {th }}$ of February 2020, the Ministry of Education of China decided to implement a full transition to online teaching and learning (MinistryofEducation, 2020). The decision urged universities to develop online courses with reformed content and innovative teaching methods within a relatively short period (Xinhua, 2020). By the first week of May 2020 and at an unprecedented scale, 1454 Chinese colleges and universities participated in the preparation of almost 1.1 million online courses that were delivered through 12.26 million classes. Around 1.03 million teachers and more than $\mathbf{1 7 . 7 5}$ million students participated in these courses (MinistryofEducation, 2020). Both theoretical and experimental disciplines were addressed in the courses including a wide range of subjects like engineering, arts, education, philosophy, medicine, law, agriculture, and literature (MinistryofEducation, 2020).

Many universities have already conducted a smooth and successful transition to online education. For instance, Zhejiang University has utilised the DingTalk ZJU platform and has managed to convert more than 5000 undergraduate and postgraduate programs into online courses within two weeks. The DingTalk ZJU - which is a 
live streaming app - documented a total audience of around 300,000 (Zhaohui, 2020). A similar transition was adopted in the universities of Greece (Giannoulas et al., 2021), West Sumatera (Fauzi et al., 2021), Australia (Lin and Nguyen, 2021), Poland (Migocka-Patrzałek et al., 2021), and other countries, where classroom lectures and activities were replaced by the online mode.

Some experts point out that the sudden and unexpected shift to online learning with insufficient training, inadequate bandwidth, and humble preparation has resulted in poor student experiences that cannot be sustainable (Lederman, 2020a; Lederman, 2020b). Others believe the shift has created a "new normal" that has brought priceless experience and achievements. These include ensuring continuity of the educational process by bridging the gap of not attending school, strengthening the learner-lecturer interactions via online one-toone communication, and boosting students' confidence as they were able to express themselves in a new learning environment (Lin and Nguyen, 2021; Zhaohui, 2020; Worth, 2020). The new online learning experience has changed the state of teaching and learning from "mono" and "teacher-centred" to "interactive" and "student-centred" and is necessary to create a hybrid model where the information technology and online activities will be an integral component of the education process.

\subsection{Aims and objectives}

Many previous studies in the literature have explored students' perceptions regarding the benefits and challenges brought by online classes. However, these studies looked at regular settings before 2020 - before the Covid-19 pandemic - where the classroom model dominated other models and approaches. In 2020, the Covid-19 pandemic forced a new reality where online classes became the norm, the dominant and maybe the only available teaching and learning mode. On the $26^{\text {th }}$ of February 2020, online courses replaced the traditional classroom teaching and learning settings in most Chinese universities. This study aims to examine students' experiences and perceptions of online classes during the Covid-19 pandemic. Objectives are; to explore benefits brought by online classes from students' perspective; to examine associated challenges and how they compare to challenges of regular classroom settings; to look at students' beliefs and attitudes about online classes especially when compared with classroom classes; and finally, to propose a set of improvements and suggestions.

The future of education is subject to other pandemics and emergencies. This study is important as its findings may be used to boost the preparedness for these potential future emergencies, pandemics, and uncertainties. The post-pandemic era will witness a new reality where a blended model that combines both classroom and online models might be adopted. An online model that brings challenges and obstacles without appropriate solutions might not be sustainable in the long term. So, the findings of the study may be used to improve the online model of the post-pandemic era and to enhance its sustainability.

The present study aims to answer the following research questions:

1. What benefits did online classes bring to students during the lockdown period?

2. What challenges did students encounter with the online experience?

3. What are students' beliefs, attitudes, and overall evaluation of online classes especially when compared with face-to-face classes?

4. What improvements are required, needed to enhance the online classes experience?

\section{Literature review}

\subsection{Benefits}

When compared to the classroom mode, online classes feature extensive flexibility that is essential during the pandemic (Lin and Hsieh, 2001). Students have more control over learning materials; they may choose the appropriate access time, sequence, pace, and amount of information and may follow a more individualised approach. Storing audio, video, electronic notes, slides, and guidelines on online platforms that can be accessed at any time - and anywhere - enhances the online settings' flexibility. Having more control over the learning process is linked to better academic performance (Hung et al., 2010; Wang and Beasley, 2002). Online classes and relevant tools are easily accessible via a wide range of technologies that can be effortlessly operated and adopted by both students and teachers (Fauzi et al., 2021). Another benefit is that online classes feature a greater outreach and ensure better access to education particularly for students with disabilities and those with medical conditions, like being infected with Covid-19 and other diseases (Migocka-Patrzałek et al., 2021). 
During the Covid-19 pandemic, many students felt isolated and disconnected. Online classes create a sense of community where students can embrace discomfort and share worries with their peers and teachers. Online classes have constituted a shelter from negative news, pressures, and worries linked to the pandemic (Lederman, 2020a). A strong sense of belonging to the knowledge community is essential for effective knowledge building (Goodyear and Zenios, 2007). Online classes during the pandemic may offer a fun and relaxing experience while improving the mental and psychological welling of students (Lederman, 2020a; Lederman, 2020b). Also, Lin and Nguyen (2021) explain how the new online learning environment boosted learner-lecturer interactions by sending emails regularly. Writing regular emails helped some students to maintain a level of motivation especially when tutors send positive replies.

Some teachers and instructors point out that chat groups, video conferencing, voting tools, and document sharing spaces make it more effective and efficient for them to reach out to students. They emphasize that they will continue to adopt the online model in the post-pandemic era. Lin and Nguyen (2021) point out that students were required to engage in online forums and discussions and were asked to express themselves in a relatively unfamiliar space. These expectations and tasks pushed students to allocate more hours of online time to enhance their English writing and speaking skills, which were comparatively improved. Finally, Giannoulas et al. (2021) refer to the positive impact of online classes on improving students' information and communications technology use (ICT), while ilin (2019) discusses that online classes can enhance students' preparedness for future careers.

\subsection{Challenges and obstacles}

The digital pedagogy and readiness of students to enroll in online classes constitute a major challenge. While some students may have the required skills and knowledge about using technological devices, software, and the internet, others may be less techno-savvy (Hung et al., 2010; Tsai and Tsai, 2003). In online courses, students with higher computer, internet, and online communication self-efficacy perform better than those with humble digital skills. The same criteria also apply to teachers, faculty and staff (Tsai and Tsai, 2003). Familiarity with hardware and software associated with online learning might hinder not only students' comprehension but also their satisfaction (Kumar, 2015). Students' - and teachers - digital skills can indeed be improved, however, the sudden shift to the online setting during the pandemic left a relatively narrow window for such improvements and training.

The Covid-19 pandemic has significantly widened the digital divide; many students cannot equally engage in the online learning process simply because they do not have home-based access to adequate technological devices and/or stable internet connections. The digital gap exists in both developed and developing countries; however, it is more prominent in the latter (UnitedNations, 2020). Students from poor and less-affluent families are left behind because of the substantial costs of digital devices and data plans (Tam and Elazar, 2020).

Another technology-related aspect is that the intensified use of digital technologies might raise security concerns. During the Covid-19 pandemic, phishing scams and online fraud cases have significantly increased, and many academic institutions suffered from online attacks (UnitedNations, 2020). Also, the shift to online learning could significantly increase screen time, especially when most of the students already spend long periods in front of their mobile and/or laptop screens in non-education related activities. These include gaming, socialising, online shopping, and reading news (ITU-News, 2020). Looking at and sitting in front of screens for extended periods is associated with several health issues such as computer vision syndrome, sleep disorders, chronic neck, back, shoulder, and muscle pain (Pandika, 2016).

Students' nature of participation and engagement in online classes constitute a significant challenge that is governed by many factors. While some students actively engage in discussions and arguments, others prefer to only listen and observe (Vonderwell and Zachariah, 2005). In their study on 96 undergraduate students, Wise et al. (2013) found that students spend around $75 \%$ of their time listening and observing. The size of the online class is also linked to the extent to which students are willing to participate; small- and medium-sized classes feature more participation than large-sized classes (Parks-Stamm, Zafonte and Palenque, 2017).

Adaptability constitutes another major challenge. Shifting from face-to-face to an online environment requires time to allow students to adapt and get accustomed to the new setting. Again, the unexpected shift to online mode may not offer sufficient time for such adaptability, especially for students with traditional mindsets who typically resist sudden changes (Kebritchi, Lipschuetz and Santiague , 2017; Kumar, 2015). 
During the lockdown, many students left their dorms and went back to their family homes, where family members are squeezed into a few rooms. Due to space limitations and competition with other members in their households, students might not have a private or quiet study space (Reidy, 2020). Moreover, students might be distracted with family-related activities and responsibilities, such as taking care of a sick family member or helping in household tasks. Also, while some parents might be supportive and helpful, others could negatively impact students' ability to learn (Zaremba, 2019).

Traditionally, classroom lectures can last for around three hours, where students constantly have face-to-face interactions with their teachers. However, in prolonged online classes, students might feel bored or even distracted (Gewin, 2020). Digital distraction during online classes is common among students as they spend years of their lives building the idea that mobile phones and laptop screens' main function is to passively consume rapidly changing media content (Worth, 2020). What complicated the issue is that during the Covid-19 pandemic negative - and sometimes fake - pandemic-related news, statistics, conspiracy theories, maps, charts, and information were circulating via digital platforms (Carmichael and Spring, 2020; Easton, 2020). These constituted additional distractions that might impose mental pressure on students and hence affect their ability to stay focused. To learn effectively via digital tools, students must spend persistent cognitive efforts battling temptations and digital distractions (Worth, 2020).

Because of the sudden shift to online evaluation and assessment, students are facing a degree of disruption accompanied by worries and concerns about their future. Performing a valid, fair, and secure assessment may be difficult (Kaup et al., 2020), and lab, practical and performance tests cannot be conducted online (Sahu, 2020).

The mental and psychological well-being of students during the pandemic might be negatively affected. The lack of physical support from teachers, peers, and in-campus student services plus new pedagogy techniques, worries, fears, isolation, depressions, and anxieties linked to the Covid-19 may hinder the ability of students to perform to their full potential (Kaup et al., 2020).

The expectations and thoughts of students can also be challenging. Some students may expect instant feedbacks on their assignments or may request a swift response to their emails. They may debate their grades and request further detailed feedbacks. Others may not take the online course or assignment deadlines seriously (Luyt, 2013; Lyons, 2004).

\subsection{Conducting online courses}

There are different methods through which online courses are conducted in universities. Some courses offer a set of pre-recorded video and audio lectures, slides and relevant materials, whereas others require students to attend live lectures via apps and software like Zoom and Microsoft Teams (Migocka-Patrzałek et al., 2021; Lin and Nguyen, 2021; Giannoulas et al., 2021). In China, live-streaming apps like DingTalk, Tencent Meetings, and Tencent QQ are commonly used, especially during the Covid-19 pandemic. DingTalk was originally developed as an internal communication platform for commercial use in an office setting. During the pandemic, the platform became popular in the educational field and was recommended to students and teachers by the IT departments of different universities.

In the Hunan Railway Professional Technology College, and since the earliest months of the pandemic outbreak, students were grouped into different online classes via DingTalk and got invitations to use the app. DingTalk was mostly used for conducting live lectures, and students' attendance was compulsory. Besides live streaming, the app offered several features. For instance, the 'Save Playback' allows lectures to be recorded, whereas the 'Support Go Live' allows participants to interact using the microphone, and through the 'Thumb-up' feature students can raise their hands and give likes. Recordings of lectures, slides, tasks, materials and online copies of textbooks were uploaded to an online cloud platform, to which students have access and through which they submitted their assignments and homework. These were necessary especially when students could not have access to paper copies of textbooks as these were only available at the campus.

\section{Methods}

\subsection{Context and participants}

To explore students' perceptions, the study used an online questionnaire. In May 2020, the questionnaire was administrated to 342 undergraduate students of the Business English and Ecommerce majors at the Economics 
and Trading department of the Hunan Railway Professional Technology College in China. This group of students were selected because online learning activities constitute an essential part of their studies, and they are expected to engage in professional online tasks in their future career. Online classes started from the 26th of February 2020, each class lasted for two teaching hours, where each teaching hour equals 45 minutes. Online classes were conducted using the DingTalk platform, and students were allowed to interact with their teachers - and to some extent with their peers. Teachers embedded some student-engaging activities where students participated in dialogues and expressed their opinions at the end of each lecture. Outside lectures, students were also allowed to communicate with their teachers via emails and other chatting platforms offered via DingTalk. All classes were recorded and stored to allow students to access them asynchronously. Similarly, all slides, videos, notes, reading, and other learning-related materials were stored. The size of online classes ranged from 32 to 110 students, who had an average of 25 hours of live-streaming lectures per week.

\subsection{Data collection}

The questionnaire was developed via the WJX.CN platform using its 'Star Survey' tool. The platform is renowned in China and is used by different academic, financial, and research institutions including the universities of Peking, Tsinghua, and Shanghai Jiao Tong. A survey link was created and then distributed to students via the online study group. The data collection process lasted for one month, from the $26^{\text {th }}$ of May to the $25^{\text {th }}$ of June 2020. Since online courses started on the $26^{\text {th }}$ of February 2020, students had experienced online classes for at least three months before participating in the study. The survey was available in Mandarin; China's official language. To test its legibility, readability, and comprehension, the survey was tested with a small group of 16 students and 3 teachers. Participants' feedback was used to revise and upgrade the survey before full implementation.

The survey began with a participant information sheet, explaining the nature of the survey and its purpose. Seeking transparent, meaningful, and realistic answers, participation in the survey was anonymous, and students were not asked to provide any contact details like names, emails, addresses, or contact numbers. All students were expected to respond to the survey. Also, they were asked not to speed through questions and to think carefully before providing each answer.

The questionnaire comprised a combination of 23 closed-ended and open-ended questions that were classified into four inquiries. The first inquiry explored benefits perceived by students from online classes during the pandemic, while the second inquiry examined the perceived challenges and obstacles. Two lists of benefits and challenges were presented and from which students were able to select. Students were able to select all applicable options. The third inquiry looked at students' beliefs, views, satisfaction, and overall evaluation of online classes, especially when compared with classroom ones. The final inquiry presented a set of potential improvements that could be applied to online classes and the online teaching and learning model in the future and explored the extent to which students agreed or disagreed with them.

The design of the survey and selecting its elements was based on existing and validated knowledge in the field. Insights were collected from online learning-related literature like Kebritchi, Lipschuetz and Santiague, (2017), Song et al. (2004), Rost (2019), illin (2019) and the Covid-19 related challenges as discussed by Lederman (2020a), Lederman (2020b), Sahu (2020), Gewin (2020), and others. Equally, the survey was influenced by the Information and Communication Technology (ICT) Familiarity and Wellbeing questionnaires of the Organisation for Economic Cooperation and Development (OECD) and the Digital Experience Survey of Higher Education Students in the UK, see OECD (2018b), OECD (2018a), OECD (2018c), and Langer-Crame et al. (2019) respectively.

Open-ended questions were included to obtain more in-depth information regarding students' perceptions of online classes during the pandemic. Answers to these questions enriched findings and added additional items that were not originally presented by the researcher. In other words, the open-ended questions documented additional benefits, challenges, and improvements of which the researcher was not aware.

In total, 342 complete and valid responses were collected. The literature suggests that the quality of collected data declines when surveys take longer than 20 minutes to answer, and the optimum threshold is 15 to 20 minutes (Versta, 2011). The questionnaire's average response time was 16 minutes. 


\subsection{Data analysis}

The quantitative data collected through the online survey were analysed and presented using Microsoft Excel and the analytics tool offered by the WJX.CN platform. A content analysis approach was adopted to process responses to open-ended questions of the questionnaire. Content analysis is defined as a research method that systematically and objectively offers valid inferences from verbal, visual, or written data (Bengtsson, 2016). It reduces the volume of text gathered, distinguishes, and classifies categories together and attempts to find some understanding of responses to open-ended questions (Richards and Morse, 2019; Silverman, 2019). Most importantly, to achieve trustworthiness, the researcher should, where possible stay 'true' and 'close' to the text without changing its original meaning (Bengtsson, 2016). Also, to achieve reliability, the authority of the researcher should be precluded (Berelson, 1952). Elo et al. (2014) suggest that ensuring the credibility of the content analysis process comprises the selection of a meaningful and suitable unit of analysis, and a unit can be a word, a letter, or a sentence. The unit of analysis should not be too broad as it will then be difficult to manage, also it should not be too narrow as this may result in fragmentation. Rather, a unit of analysis should be sufficiently large to be considered as a whole but small enough to be meaningful. In line with the previous definition and guidelines, the author selected a set of units of analysis for each open-ended question and then counted the number of responses mentioning each unit. Units like 'quitter and calmer environment', 'poor class management', and 'stressful and confused' were selected and tracked in students' responses. The content analysis process allowed responses to open-ended questions to be filtered, summarised, classified and represented in tables with neither changing their content nor personal intervention from the researcher. It is worth mentioning that the content analysis approach adopted in this study does not follow the strictest methodology, still, it constitutes a valid one following the broader notion and definition of content analysis as discussed in Bengtsson (2016).

\section{Results}

\subsection{Perceived benefits}

The first inquiry examined the benefits and advantages of online classes as perceived by students. Table 1 presents these benefits and sorts them by the most selected ones. The most significant benefit from students' perspective was creating a digital community where questions can be posted, followed by enhancing students' familiarity with digital learning technologies, with almost $92 \%$ and $90 \%$ respectively. Creating a sense of community, belonging, connecting, and embracing discomfort with others plus feeling supported during tough times were also significant benefits perceived by at least $70 \%$ of students. Moreover, at least half of the students stated that online classes offered shelter from daily negative news, made them less fragile, and boosted their preparedness for similar future emergencies and uncertainties. Thirty nine percent of students agreed that practising during online classes made them feel more confident and prepared for their future careers, whereas around $29 \%$ disagreed on perceiving such benefits. At the same time, $33 \%$ of students had neutrally responded to the item as they neither agreed nor disagreed to perceiving it.

Table 1: Perceived benefits of online classes during the pandemic

\begin{tabular}{|c|c|c|c|}
\hline Perceived benefits and advantages $(n=342)$ & Agree & Disagree & $\begin{array}{l}\text { Neither agree nor } \\
\text { disagree }\end{array}$ \\
\hline $\begin{array}{l}\text { Online classes created a digital community where I was able to post } \\
\text { questions and inquires, and share materials }\end{array}$ & $\begin{array}{l}314 \\
(91.81 \%)\end{array}$ & $\begin{array}{l}16 \\
(4.68 \%)\end{array}$ & $\begin{array}{l}12 \\
(3.51 \%)\end{array}$ \\
\hline $\begin{array}{l}\text { Online classes enhanced my familiarity with digital learning } \\
\text { technologies and allowed access to further learning materials }\end{array}$ & $\begin{array}{l}308 \\
(90.06 \%)\end{array}$ & $\begin{array}{l}20 \\
(5.85 \%)\end{array}$ & $\begin{array}{l}14 \\
(4.09 \%)\end{array}$ \\
\hline $\begin{array}{l}\text { Online classes made me feel connected with others during the } \\
\text { pandemic, they created a sense of community }\end{array}$ & $\begin{array}{l}248 \\
(72.51 \%)\end{array}$ & $\begin{array}{l}40 \\
(11.7 \%)\end{array}$ & $54(15.79 \%)$ \\
\hline $\begin{array}{l}\text { Online classes made me embrace discomfort together with other } \\
\text { students }\end{array}$ & $\begin{array}{l}248 \\
(72.51 \%)\end{array}$ & $\begin{array}{l}40 \\
(11.7 \%)\end{array}$ & $54(15.79 \%)$ \\
\hline Online classed featured a study-life balance during the pandemic & $\begin{array}{l}244 \\
(71.35 \%)\end{array}$ & $\begin{array}{l}60 \\
(17.54 \%)\end{array}$ & $38(11.11 \%)$ \\
\hline Online classes made me feel supported in such tough times & $\begin{array}{l}238 \\
(69.59 \%)\end{array}$ & $\begin{array}{l}54 \\
(15.79 \%)\end{array}$ & $50(14.62 \%)$ \\
\hline $\begin{array}{l}\text { Online classes featured a relaxing and fun experience that enriched } \\
\text { my life during the pandemic }\end{array}$ & $\begin{array}{l}200 \\
(58.48 \%)\end{array}$ & $\begin{array}{l}70 \\
(20.47 \%)\end{array}$ & $72(21.05 \%)$ \\
\hline Online classes improved my mental and psychological welling & $\begin{array}{l}192 \\
(56.14 \%)\end{array}$ & $\begin{array}{l}82 \\
(23.98 \%)\end{array}$ & $68(19.88 \%)$ \\
\hline
\end{tabular}




\begin{tabular}{|c|c|c|c|}
\hline Perceived benefits and advantages $(n=342)$ & Agree & Disagree & $\begin{array}{l}\text { Neither agree nor } \\
\text { disagree }\end{array}$ \\
\hline $\begin{array}{l}\text { Online classes offered an escape from daily pressures and reduced } \\
\text { my exposure to the massive amount of negative news }\end{array}$ & $\begin{array}{l}192 \\
(56.14 \%)\end{array}$ & $\begin{array}{l}98 \\
(28.65 \%)\end{array}$ & $\begin{array}{l}52 \\
(15.2 \%)\end{array}$ \\
\hline $\begin{array}{l}\text { Online classes made me feel less fragile and more ready for similar } \\
\text { future uncertainties and circumstances }\end{array}$ & $\begin{array}{l}190 \\
(55.56 \%)\end{array}$ & $\begin{array}{l}82 \\
(23.98 \%)\end{array}$ & $70(20.47 \%)$ \\
\hline $\begin{array}{l}\text { Practising during online classes made me feel more confident and } \\
\text { prepared for my future career }\end{array}$ & $\begin{array}{l}132 \\
(38.6 \%)\end{array}$ & $\begin{array}{l}98 \\
(28.65 \%)\end{array}$ & $112(32.75 \%)$ \\
\hline
\end{tabular}

In addition to the benefits presented in Table 1, an open-ended question asked students to think of additional benefits brought by online classes during the pandemic. Students stated that they perceived further benefits including strengthening self-learning skills and self-discipline, flexibility, convenience. Student A commented "online classes facilitate a gradual transition to modernisation...they are enriching the content of courses", while student B stated "online classes allowed me to exercise my mental endurance during such tough times". Benefits derived from the open-ended question are listed in Table 2.

Table 2: additional benefits perceived by students and expressed through an open-ended question

\begin{tabular}{l|l|}
$\begin{array}{l}\text { Perceived benefits expressed through the open-ended question (n=342) } \\
\begin{array}{l}\text { Online classes featured flexibility, convenience, and more control over the learning } \\
\text { process }\end{array}\end{array}$ & $\begin{array}{l}\text { Frequency of mentioning each } \\
\text { benefit }\end{array}$ \\
\hline $\begin{array}{l}\text { Online classes strengthened my self-learning skills and self-discipline } \\
\text { The pandemic abrupted the educational process while online classes bridge the gap } \\
\text { and featured continuity }\end{array}$ & 60 \\
\hline $\begin{array}{l}\text { Online classes allowed me to watch playbacks and to repeatedly access recorded } \\
\text { materials }\end{array}$ & 30 \\
\hline \begin{tabular}{l} 
Online classes featured a quieter and calmer environment \\
\hline
\end{tabular}
\end{tabular}

\subsection{Perceived Challenges}

The second inquiry was related to challenges perceived by students and that negatively impacted their learning experience during online classes. Table 3 presents these challenges and sorts them by the most selected ones. Each of the top three challenges was selected by more than half of the 342 students. The sudden shift to the online mode meant that additional time was required to get accustomed to the new learning delivery method, and this challenge ranked first and was selected by around $75 \%$ of students. The second most selected category was having time-management issues, while the third challenge was being distracted by social media, surfing the internet, and other online activities during online classes, with $59 \%$ and $58.5 \%$ respectively. Other significant challenges were related to demanding assignments and technical issues with $46.8 \%$ and $44.4 \%$ of students selecting these categories. Moreover, around $43 \%$ of respondents found the design of online classes boring and were sometimes bored or absent-minded. Surprisingly, categories that were directly linked to Covid-19 did not impose significant challenges. For instance, less than $10 \%$ of students were worried or paranoid about their health. Likewise, almost the whole sample stated that they were neither sick nor living with a sick family member.

Table 3: perceived challenges of online classes during the pandemic

\begin{tabular}{|c|c|c|c|}
\hline Perceived challenges $(n=342)$ & Agree & Disagree & $\begin{array}{l}\text { Neither agree } \\
\text { nor disagree }\end{array}$ \\
\hline $\begin{array}{l}\text { Adaptability issues: the sudden shift to online classes meant that I need } \\
\text { additional study time to get accustomed to the new learning style and } \\
\text { technology }\end{array}$ & $\begin{array}{l}258 \\
(75.44 \%)\end{array}$ & $\begin{array}{l}64 \\
(18.71 \%)\end{array}$ & $\begin{array}{l}20 \\
(5.85 \%)\end{array}$ \\
\hline I had time-management issues & $\begin{array}{l}202 \\
(59.06 \%)\end{array}$ & $\begin{array}{l}80 \\
(23.39 \%)\end{array}$ & $\begin{array}{l}60 \\
(17.54 \%)\end{array}$ \\
\hline $\begin{array}{l}\text { During the online class, I was distracted by social media, surfing the } \\
\text { internet, or other online activities }\end{array}$ & $\begin{array}{l}200 \\
(58.48 \%)\end{array}$ & $\begin{array}{l}102 \\
(29.82 \%)\end{array}$ & $\begin{array}{l}40 \\
(11.7 \%)\end{array}$ \\
\hline $\begin{array}{l}\text { Homework and assignments were very demanding while my time was } \\
\text { very limited during the pandemic }\end{array}$ & $\begin{array}{l}160 \\
(46.78 \%)\end{array}$ & $\begin{array}{l}140 \\
(40.94 \%)\end{array}$ & $42(12.28 \%)$ \\
\hline $\begin{array}{l}\text { I met technical issues with one or more of the following: hardware, } \\
\text { software, internet connection }\end{array}$ & 152 & 148 & $42(12.28 \%)$ \\
\hline $\begin{array}{l}\text { The design of the online class and its activities were boring, and } \\
\text { sometimes, I was absent-minded }\end{array}$ & $\begin{array}{l}146 \\
(42.69 \%)\end{array}$ & $\begin{array}{l}138 \\
(40.35 \%)\end{array}$ & $58(16.96 \%)$ \\
\hline
\end{tabular}




\begin{tabular}{|c|c|c|c|}
\hline Perceived challenges $(n=342)$ & Agree & Disagree & $\begin{array}{l}\text { Neither agree } \\
\text { nor disagree }\end{array}$ \\
\hline I met Covid 10-related financial difficulties & $\begin{array}{l}130 \\
(38.01 \%)\end{array}$ & $\begin{array}{l}182 \\
(53.22 \%)\end{array}$ & $\begin{array}{l}30 \\
(8.77 \%)\end{array}$ \\
\hline I cannot sit for long continuous periods in front of the screen & $\begin{array}{l}128 \\
(37.43 \%)\end{array}$ & $\begin{array}{l}182 \\
(53.22 \%)\end{array}$ & $\begin{array}{l}32 \\
(9.36 \%)\end{array}$ \\
\hline I was shy to introduce myself and participate in the online classes & 128 & $\begin{array}{l}152 \\
(44.44 \%)\end{array}$ & $62(18.13 \%)$ \\
\hline $\begin{array}{l}\text { I had many responsibilities to take care of, and the online classes did not } \\
\text { afford me the flexibility }\end{array}$ & $\begin{array}{l}122 \\
(35.67 \%)\end{array}$ & $\begin{array}{l}144 \\
(42.11 \%)\end{array}$ & $76(22.22 \%)$ \\
\hline $\begin{array}{l}\text { My digital pedagogy is relatively limited and not enough to meet the } \\
\text { requirements of the online classes }\end{array}$ & $\begin{array}{l}104 \\
(30.41 \%)\end{array}$ & $\begin{array}{l}176 \\
(51.46 \%)\end{array}$ & $62(18.13 \%)$ \\
\hline $\begin{array}{l}\text { Due to the lack of self-discipline, I cannot learn independently and the } \\
\text { presence of a teacher in the class is vital to me }\end{array}$ & $\begin{array}{l}98 \\
(28.65 \%)\end{array}$ & $\begin{array}{l}190 \\
(55.56 \%)\end{array}$ & $54(15.79 \%)$ \\
\hline $\begin{array}{l}\text { In the absence of face-to-face interactions with both my classmates and } \\
\text { the teacher, I was not able to practice my spelling and communication } \\
\text { skills }\end{array}$ & $\begin{array}{l}92 \\
(26.9 \%)\end{array}$ & $\begin{array}{l}230 \\
(67.25 \%)\end{array}$ & $\begin{array}{l}20 \\
(5.85 \%)\end{array}$ \\
\hline $\begin{array}{l}\text { The Teacher's digital pedagogy was relatively limited and that degraded } \\
\text { the quality of the online course }\end{array}$ & $\begin{array}{l}88 \\
(25.73 \%)\end{array}$ & $\begin{array}{l}208 \\
(60.82 \%)\end{array}$ & $46(13.45 \%)$ \\
\hline $\begin{array}{l}\text { I was worried and paranoid about the potential impacts of the pandemic } \\
\text { on my future career }\end{array}$ & $\begin{array}{l}84 \\
(24.56 \%)\end{array}$ & $\begin{array}{l}212 \\
(61.99 \%)\end{array}$ & $46(13.45 \%)$ \\
\hline $\begin{array}{l}\text { During the online classes, the presence of teacher was dominant while } \\
\text { much less space was given to me and other students to interact and } \\
\text { engage }\end{array}$ & $\begin{array}{l}80 \\
(23.39 \%)\end{array}$ & $\begin{array}{l}216 \\
(63.16 \%)\end{array}$ & $46(13.45 \%)$ \\
\hline $\begin{array}{l}\text { In contrast to face-to-face classes, online classes did not feature a sense } \\
\text { of community, and the interaction with classmates and teachers was very } \\
\text { poor }\end{array}$ & $\begin{array}{l}78 \\
(22.81 \%)\end{array}$ & $\begin{array}{l}208 \\
(60.82 \%)\end{array}$ & $56(16.37 \%)$ \\
\hline $\begin{array}{l}\text { The shift to online classes was sudden and unexpected, and I was not } \\
\text { prepared for such a fortuitous transformation }\end{array}$ & $\begin{array}{l}78 \\
(22.81 \%)\end{array}$ & $\begin{array}{l}232 \\
(67.84 \%)\end{array}$ & $\begin{array}{l}32 \\
(9.36 \%)\end{array}$ \\
\hline $\begin{array}{l}\text { I did not have a quiet or adequate personal space during the online } \\
\text { classes, and I was surrounded by external distractions }\end{array}$ & $\begin{array}{l}64 \\
(18.71 \%)\end{array}$ & $\begin{array}{l}230 \\
(67.25 \%)\end{array}$ & $48(14.04 \%)$ \\
\hline My family met Covid19-related financial difficulties & $\begin{array}{l}60 \\
(17.54 \%)\end{array}$ & $\begin{array}{l}226 \\
(66.08 \%)\end{array}$ & $56(16.37 \%)$ \\
\hline Instructions, guidelines, and teachers' expectations were not clear to me & $\begin{array}{l}28 \\
(8.19 \%)\end{array}$ & $\begin{array}{l}288 \\
(84.21 \%)\end{array}$ & $\begin{array}{l}26 \\
(7.6 \%)\end{array}$ \\
\hline I was worried and paranoid about my health all the time & $\begin{array}{l}26 \\
(7.6 \%)\end{array}$ & $\begin{array}{l}280 \\
(81.87 \%)\end{array}$ & $36(10.53 \%)$ \\
\hline $\begin{array}{l}\text { Conflicts between family members and domestic violence imposed } \\
\text { serious distractions that hindered my ability to learn }\end{array}$ & $\begin{array}{l}22 \\
(6.43 \%)\end{array}$ & $\begin{array}{l}306 \\
(89.47 \%)\end{array}$ & $\begin{array}{l}14 \\
(4.09 \%)\end{array}$ \\
\hline I was very sick as I was infected by Covid & $\begin{array}{l}0 \\
(0 \%)\end{array}$ & $\begin{array}{l}336 \\
(98.25 \%)\end{array}$ & $\begin{array}{l}6 \\
(1.75 \%)\end{array}$ \\
\hline A member of my family was very sick & $\begin{array}{l}0 \\
(0 \%)\end{array}$ & $\begin{array}{l}340 \\
(99.42 \%)\end{array}$ & $\begin{array}{l}2 \\
(0.58 \%)\end{array}$ \\
\hline
\end{tabular}

An in-depth exploration of technology-related challenges is presented in Table 4. Suffering from back pain and/or digital eye strain due to sitting for prolonged periods in front of the screen was the most prominent challenge, with 272 students perceiving this issue. However, each other technology-related challenge was perceived by less than $25 \%$ of respondents. Only $25 \%$ of students found it hard to access online study-related materials and $16 \%$ did not have Wi-Fi. Only 16 out of 342 students did not have personal digital devices for study purposes.

Table 4: perceived technology-related challenges

\begin{tabular}{|l|l|l|l|}
\hline Perceived technology-related challenges $(\mathbf{n}=\mathbf{3 4 2})$ & Agree & Disagree & $\begin{array}{l}\text { Neither } \\
\text { agree nor } \\
\text { disagree }\end{array}$ \\
\hline $\begin{array}{l}\text { I suffered from back pain and/or digital eye strain due to sitting for } \\
\text { prolonged periods in front of the screen }\end{array}$ & $\begin{array}{l}272 \\
(79.53 \%)\end{array}$ & $\begin{array}{l}56 \\
(16.37 \%)\end{array}$ & $\begin{array}{l}14 \\
(4.09 \%)\end{array}$ \\
\hline $\begin{array}{l}\text { It was hard to access study-related resources such as online libraries and } \\
\text { online databases }\end{array}$ & $82(23.98 \%)$ & 242 \\
$\left(\begin{array}{l}70.76 \%) \\
\text { I could not reach out for help regarding technological difficulties and } \\
\text { issues }\end{array}\right.$ & $80(23.39 \%)$ & 236 \\
\hline
\end{tabular}




\begin{tabular}{|c|c|c|c|}
\hline Perceived technology-related challenges $(n=342)$ & Agree & Disagree & $\begin{array}{l}\text { Neither } \\
\text { agree nor } \\
\text { disagree }\end{array}$ \\
\hline $\begin{array}{l}\text { I met problems with the software like the online learning platform/ } \\
\text { PowerPoint/others }\end{array}$ & $72(21.05 \%)$ & $\begin{array}{l}242 \\
(70.76 \%)\end{array}$ & $28(8.19 \%)$ \\
\hline $\begin{array}{l}\text { I met problems with the hardware like } \\
\text { microphone/camera/keyboard/others }\end{array}$ & $68(19.88 \%)$ & $\begin{array}{l}250 \\
(73.1 \%)\end{array}$ & $24(7.02 \%)$ \\
\hline $\begin{array}{l}\text { I did not have a stable internet connection that meets the requirements } \\
\text { of synchronous activities such as live video streaming }\end{array}$ & $\begin{array}{l}60 \\
(17.54 \%)\end{array}$ & $\begin{array}{l}266 \\
(77.78 \%)\end{array}$ & $16(4.68 \%)$ \\
\hline I did not have Wi-fi, and it was expensive to purchase data & $58(16.96 \%)$ & $\begin{array}{l}278 \\
(81.29 \%)\end{array}$ & $6(1.75 \%)$ \\
\hline $\begin{array}{l}\text { I did not have a stable internet connection that meets the requirements } \\
\text { of asynchronous activities such as searching for homework-related } \\
\text { information }\end{array}$ & $48(14.04 \%)$ & $\begin{array}{l}278 \\
(81.29 \%)\end{array}$ & $16(4.68 \%)$ \\
\hline The electricity supply was not stable in my area & $46(13.45 \%)$ & $\begin{array}{l}274 \\
(80.12 \%)\end{array}$ & $22(6.43 \%)$ \\
\hline $\begin{array}{l}\text { It was hard to navigate through course-related materials such as slides, } \\
\text { recordings, and feedbacks }\end{array}$ & $44(12.87 \%)$ & $\begin{array}{l}278 \\
(81.29 \%)\end{array}$ & $20(5.85 \%)$ \\
\hline I did not have a personal digital device and I was using others' device & $\begin{array}{l}16 \\
(4.68 \%)\end{array}$ & $\begin{array}{l}324 \\
(94.74 \%)\end{array}$ & $\begin{array}{l}2 \\
(0.58 \%)\end{array}$ \\
\hline I met online security issues such as pandemic-related fraud, spy, etc.. & $\begin{array}{l}2 \\
(0.58 \%)\end{array}$ & $\begin{array}{l}334 \\
(97.67 \%)\end{array}$ & $6(1.75 \%)$ \\
\hline
\end{tabular}

Figure 1 shows that $6 \%$ of students met technical issues that they could not solve. However, almost half of the respondents used their knowledge to solve technical issues, while almost one-third of students solved technical problems with the help of friends, family members, teachers, or IT staff.

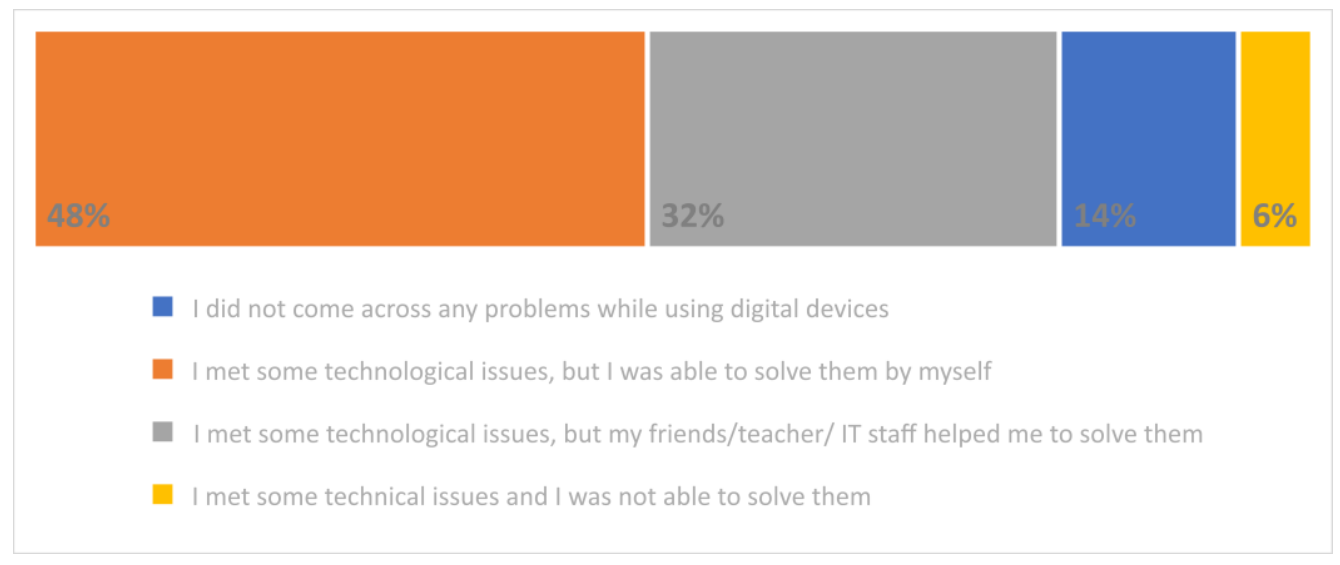

Figure 1: students' approaches to dealing with technological issues

Figure 2 illustrates that only around 13\% of students had a study space that was affected by a significant level of surrounding distractions. The rest of the students did not perceive external distractions; they either had their private study space or shared distraction-free spaces with others. 


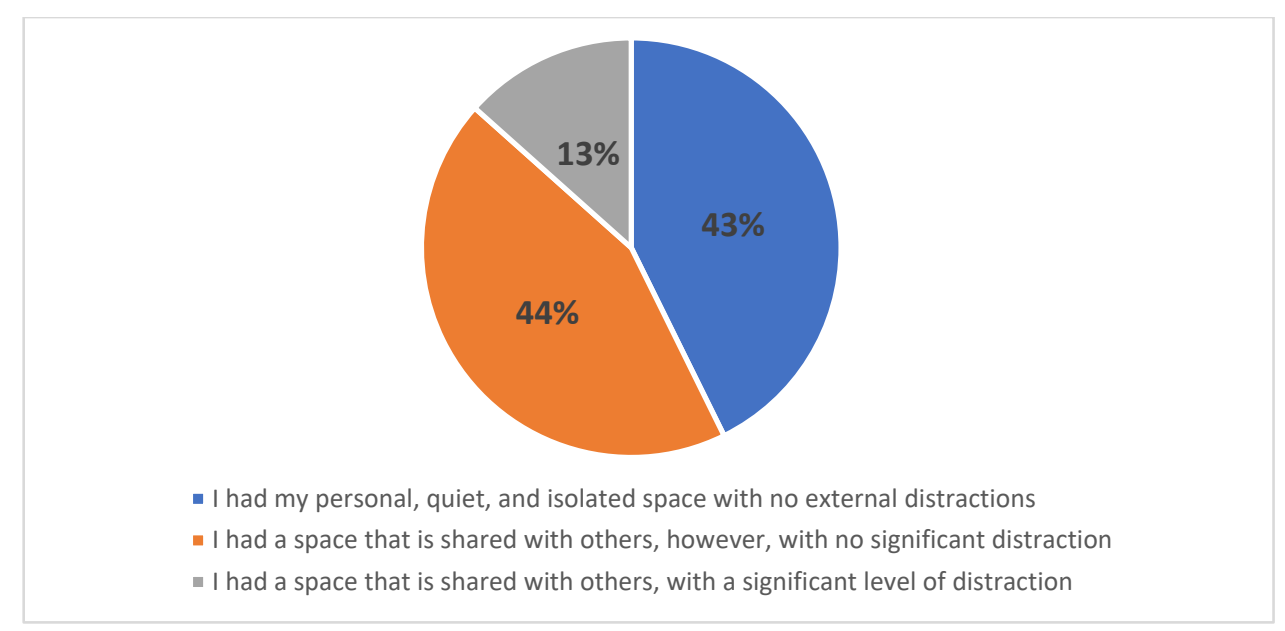

Figure 2: students' approaches to dealing with technological issues

Finally, an open-ended question allowed students to discuss further perceived challenges, and these are listed in Table 5. These include poor real-time communication at all levels; concerns and doubts about the accuracy and validity of lecture content especially in the absence of textbooks; feeling stressed or confused; poor management of the class; using several platforms and apps for several subjects; and finally, the inability to take online classes seriously. One of the students commented "I am used to my textbooks and now I have serious doubts about the integrity and validity of lectures' content".

Table 5: additional challenges perceived by students and expressed through an open-ended question

\begin{tabular}{|l|l|}
\hline Perceived challenges expressed through the open-ended question $\mathbf{( n = 3 4 2 )}$ & $\begin{array}{l}\text { Frequency of mentioning each } \\
\text { challenge }\end{array}$ \\
\hline Poor in-time communication with teachers and students & 64 \\
\hline $\begin{array}{l}\text { I cannot take online classes seriously } \\
\text { I have concerns about the validity and accuracy of content in the absence of } \\
\text { textbooks }\end{array}$ & 34 \\
\hline $\begin{array}{l}\text { Different classes mean using several platforms and apps which is demanding } \\
\text { and confusing }\end{array}$ & 16 \\
\hline $\begin{array}{l}\text { Poor class management } \\
\text { Online classes make me stressed and confused }\end{array}$ & 16 \\
\hline
\end{tabular}

\subsection{Beliefs, attitudes, views, and an overall evaluation}

The third inquiry examined students' beliefs, attitudes, and overall evaluation regarding online classes, especially when compared with face-to-face ones, see Table 6. Notably, more than half of the students stated that they did not take online classes as seriously as they take face-to-face ones. Also, they revealed that online classes did not meet their expectations as they were expecting a more engaging and exciting experience. However, $60 \%$ of students disagreed that the college was not fully prepared for the unexpected shift to online classes. Most students agreed that online classes suit some subjects more than others.

Outside online classes, the engagement with classmates was stronger than the interaction with teachers or family members. More than $90 \%$ of respondents stated that outside online classes, they used online platforms to engage in course-related discussions with classmates, compared to $70 \%$ of those who sought help from teachers or family members. Almost $47 \%$ of students believed that during online classes, teachers know little about students and the extent to which they are engaged, compared to 53\% who held an opposite belief.

Table 6: Students' beliefs and attributes towards online classes

\begin{tabular}{|l|l|l|l|l|}
\hline $\begin{array}{l}\text { Students' beliefs and attitudes towards online classes } \\
\text { (n=342) }\end{array}$ & $\begin{array}{l}\text { Strongly } \\
\text { disagree }\end{array}$ & Disagree & Agree & $\begin{array}{l}\text { Strongly } \\
\text { Agree }\end{array}$ \\
\hline $\begin{array}{l}\text { Online classes did not meet my expectations, and I was } \\
\text { expecting a more exciting and engaging experience }\end{array}$ & $20(5.85 \%)$ & 126 & 172 & 24 \\
\hline $\begin{array}{l}\text { I did not take the online classes as serious as I take the } \\
\text { face-to-face ones }\end{array}$ & $20(5.85 \%)$ & $\begin{array}{l}124 \\
(36.84 \%)\end{array}$ & $(50.29 \%)$ & 172 \\
\hline $\begin{array}{l}\text { I felt that my institution was not fully prepared for the } \\
\text { unexpected shift to online classes }\end{array}$ & $32(9.36 \%)$ & $\begin{array}{l}176 \\
\text { unes }\end{array}$ & $\begin{array}{l}26 \\
(7.6 \%)\end{array}$ \\
\hline
\end{tabular}




\begin{tabular}{|c|c|c|c|c|}
\hline $\begin{array}{l}\text { Students' beliefs and attitudes towards online classes } \\
(n=342)\end{array}$ & $\begin{array}{l}\text { Strongly } \\
\text { disagree }\end{array}$ & Disagree & Agree & $\begin{array}{l}\text { Strongly } \\
\text { Agree }\end{array}$ \\
\hline Online classes fit some subjects more than others & $\begin{array}{l}2 \\
(0.58 \%)\end{array}$ & $\begin{array}{l}20 \\
(5.85 \%)\end{array}$ & $\begin{array}{l}250 \\
(73.1 \%)\end{array}$ & $70(20.47 \%)$ \\
\hline $\begin{array}{l}\text { During online classes, teachers know little about students } \\
\text { and the extent to which they are engaged }\end{array}$ & $18(5.26 \%)$ & $\begin{array}{l}166 \\
(48.54 \%)\end{array}$ & $\begin{array}{l}136 \\
(39.77 \%)\end{array}$ & $\begin{array}{l}22 \\
(6.43 \%)\end{array}$ \\
\hline During online classes, I listened carefully and took notes & $8(2.34 \%)$ & $36(10.53 \%)$ & $\begin{array}{l}248 \\
(72.51 \%)\end{array}$ & $50(14.62 \%)$ \\
\hline $\begin{array}{l}\text { Outside the online class, I sought course-related help } \\
\text { from the teacher or family members }\end{array}$ & $\begin{array}{l}8 \\
(2.34 \%)\end{array}$ & $98(28.65 \%)$ & $\begin{array}{l}220 \\
(64.33 \%)\end{array}$ & $\begin{array}{l}16 \\
(4.68 \%)\end{array}$ \\
\hline $\begin{array}{l}\text { Outside the online class, I used online platforms to } \\
\text { engage in course-related discussions with my classmates }\end{array}$ & $\begin{array}{l}2 \\
(0.58 \%)\end{array}$ & $\begin{array}{l}28 \\
(8.19 \%)\end{array}$ & $\begin{array}{l}278 \\
(81.29 \%)\end{array}$ & $\begin{array}{l}34 \\
(9.94 \%)\end{array}$ \\
\hline
\end{tabular}

Figure 3 illustrates the overall impact of online classes on students' day-to-day life and schedule during the Covid pandemic. Half of the students believed that online classes had complemented their daily life by enriching their schedules and filling the gap of not attending school. In contrast, $24 \%$ of respondents stated that online classes had complicated their life by disturbing their already busy daily schedule and requiring them to make additional - unexpected - arrangements. The rest of the students - $26 \%$ - stated that online classes had neither complemented nor complicated their life during the pandemic. Also, Figure 3 exhibits around 37\% of students stated online classes enhanced their ability to learn, whereas exactly similar proportion stated the opposite; online classes degraded their ability to learn.

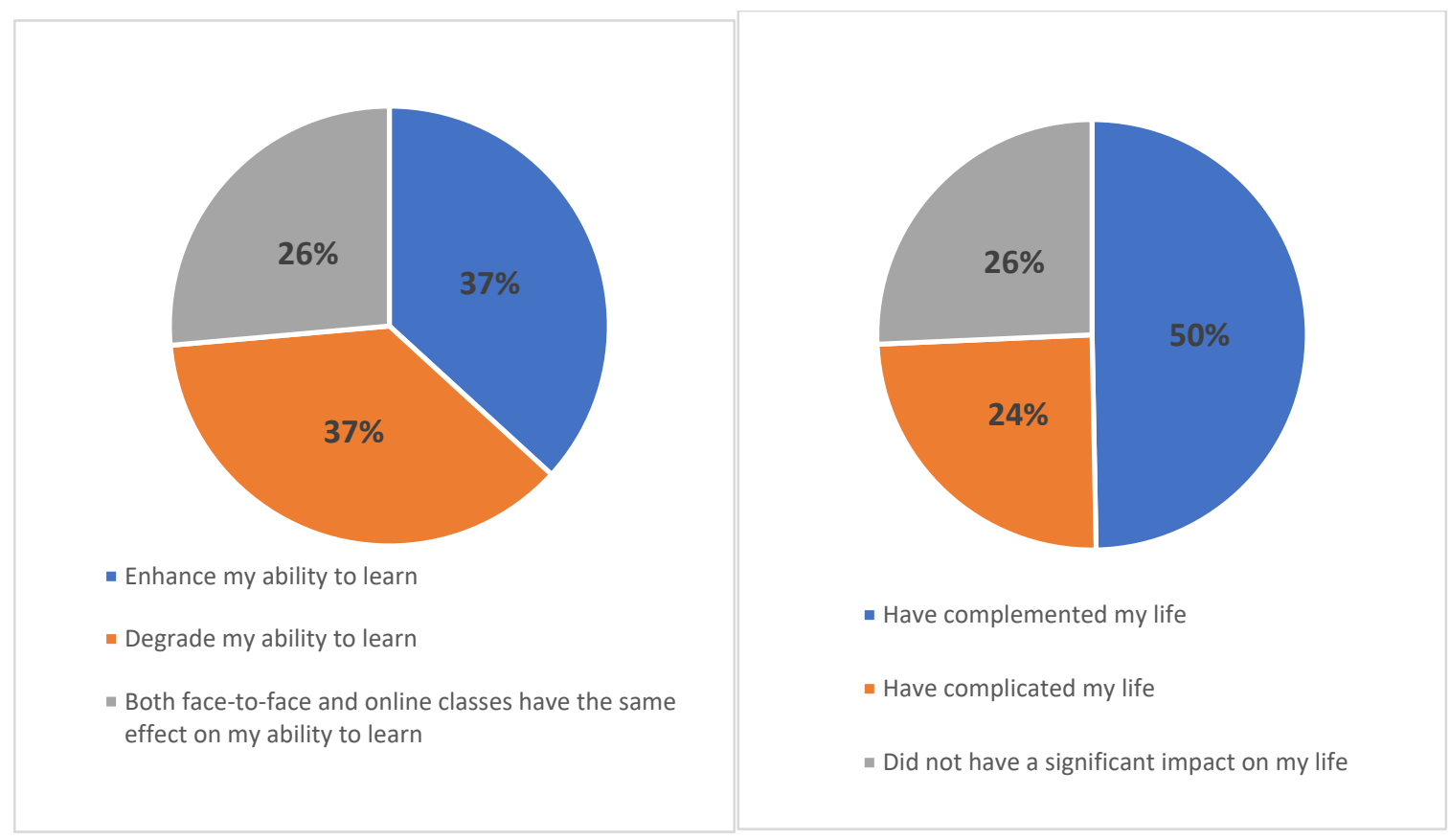

Figure 3: impacts of online classes on students' life and ability to learn

Figure 4 demonstrates that the majority of students believed classroom and online classes complement one another and are both important for future education. Only around $14 \%$ pointed out that the online model could become the new norm and could completely substitute the classroom model after the Covid-19 pandemic. The same trend persisted, and students' beliefs did not significantly change even if improvements are to be applied to the currently used online model. 


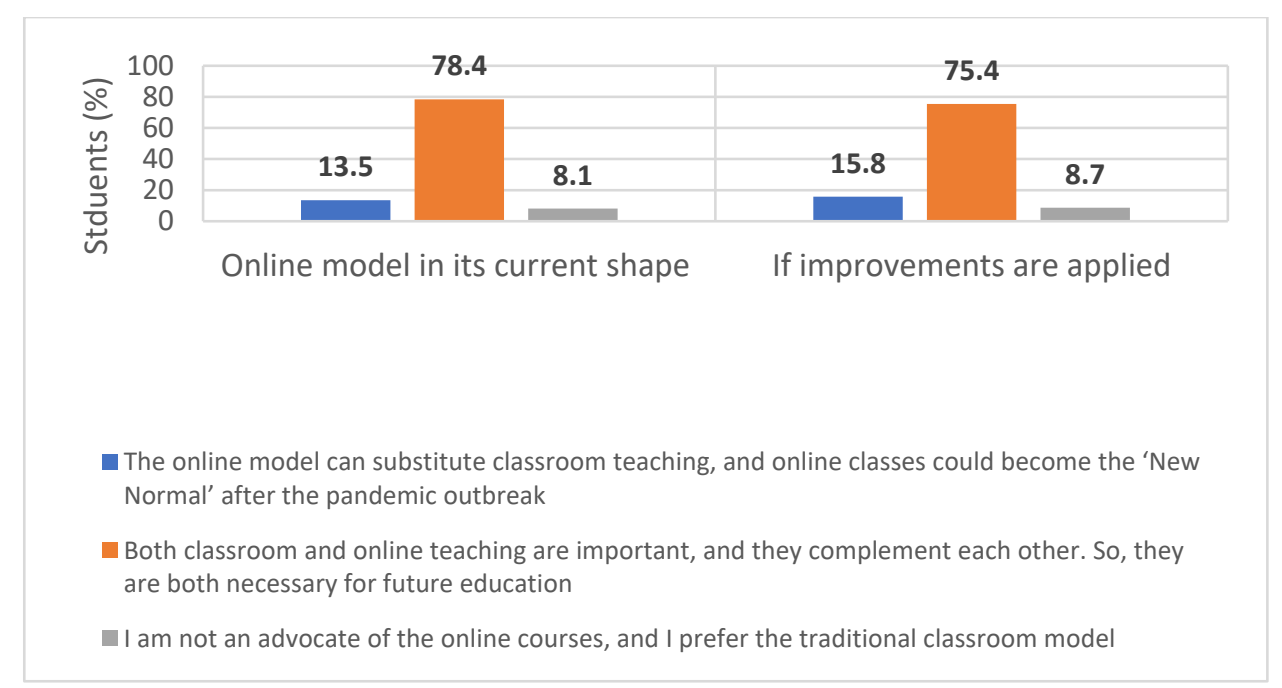

Figure 4: the most preferred mode from the students' perspective

Regarding their overall satisfaction, Figure 5 shows half of the students stated that they were equally satisfied by classroom and online learning, while around $40 \%$ were more satisfied with classroom settings. Only around $7 \%$ were more satisfied with online settings.

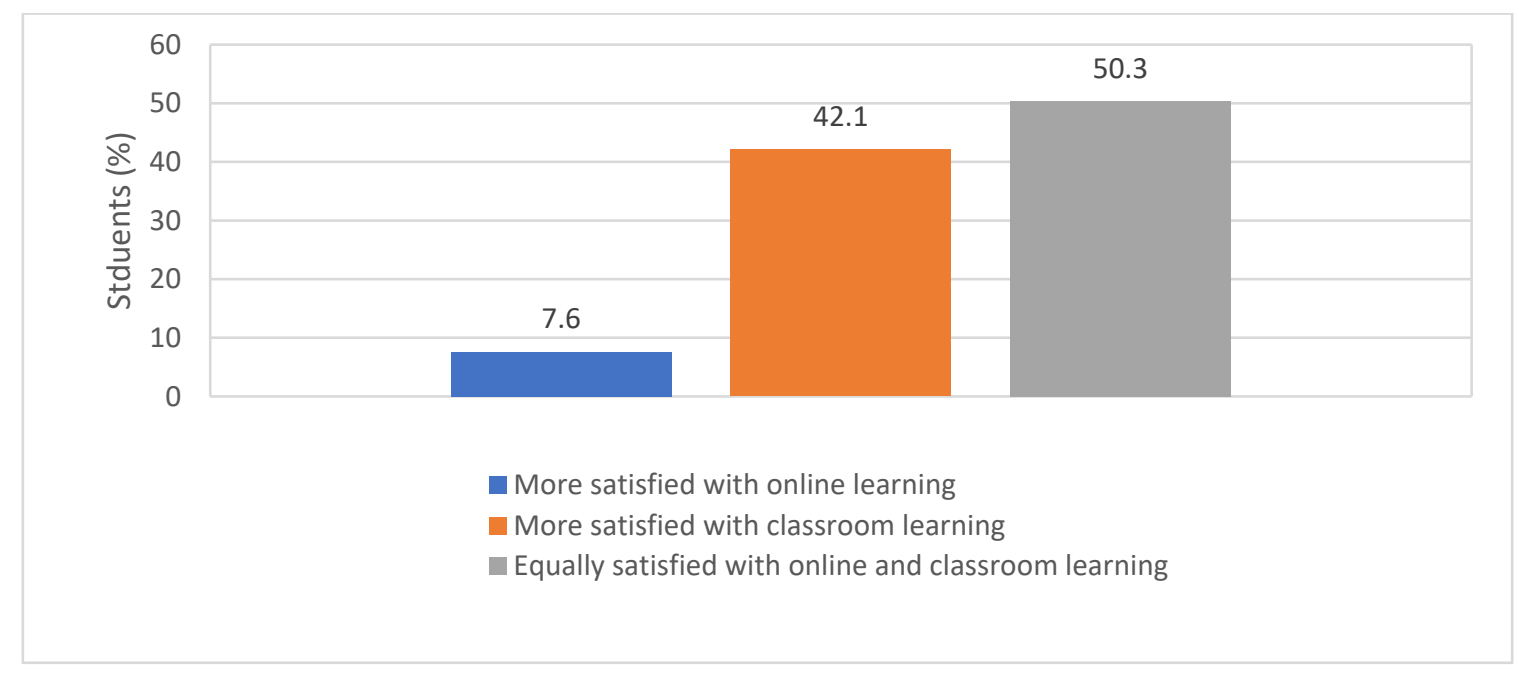

Figure 5: the most preferred mode from the students' perspective

\subsection{Improvements}

In the forth inquiry, a set of potential improvements was presented to students as in Figure 6. Most students agreed on all proposed improvements asserting their importance. For example, $75 \%$ of students agreed that teachers should discuss the mental, physical, and psychological wellbeing of their students, while an additional $20 \%$ strongly agreed on the same category. Around $90 \%$ of students advocated online activities to facilitate more participation and interaction with both peers and teachers. Similarly, almost $95 \%$ at least agreed that teachers should show more empathy during emergencies and tough times. Other proposed improvements on which students agreed included that teachers should be approachable via communication channels outside the designated online classes and the need to offer financial grants or loans to allow purchasing study-related technology devices and/or internet data. 


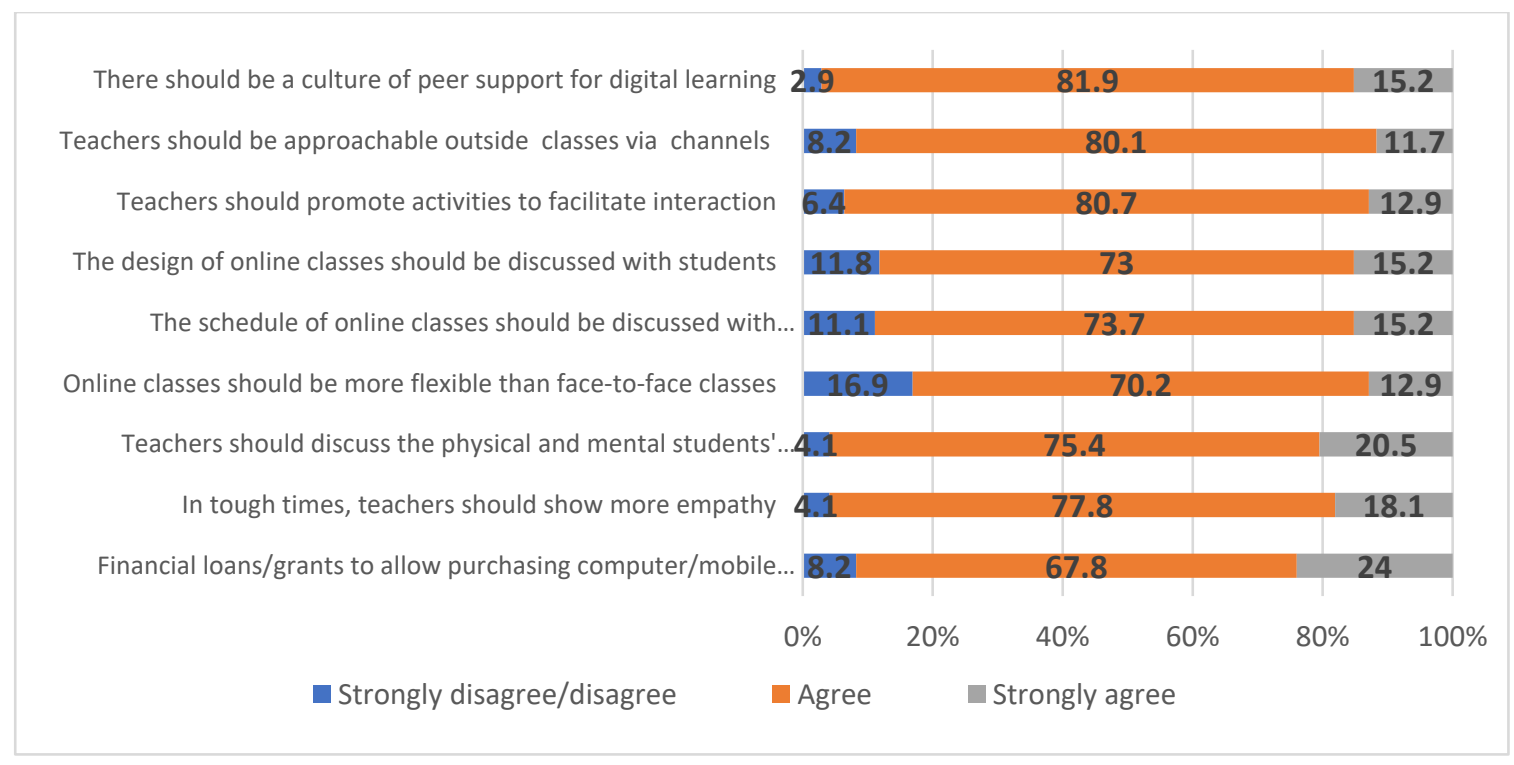

Figure 6: proposed improvements and the extent to which students agreed on them

Finally, regarding the design and delivery, Figure 7 illustrates that almost $80 \%$ of students advocated short online classes and more student-directed study time, compared to only around $20 \%$ who preferred long classes and less student-direct study time. Also, Figure 7 shows that asynchronous learning activities were more popular among respondents, where around 55\% preferred recorded lectures and notes, compared to $44 \%$ who advocated synchronous activities like live video streaming and presentations.

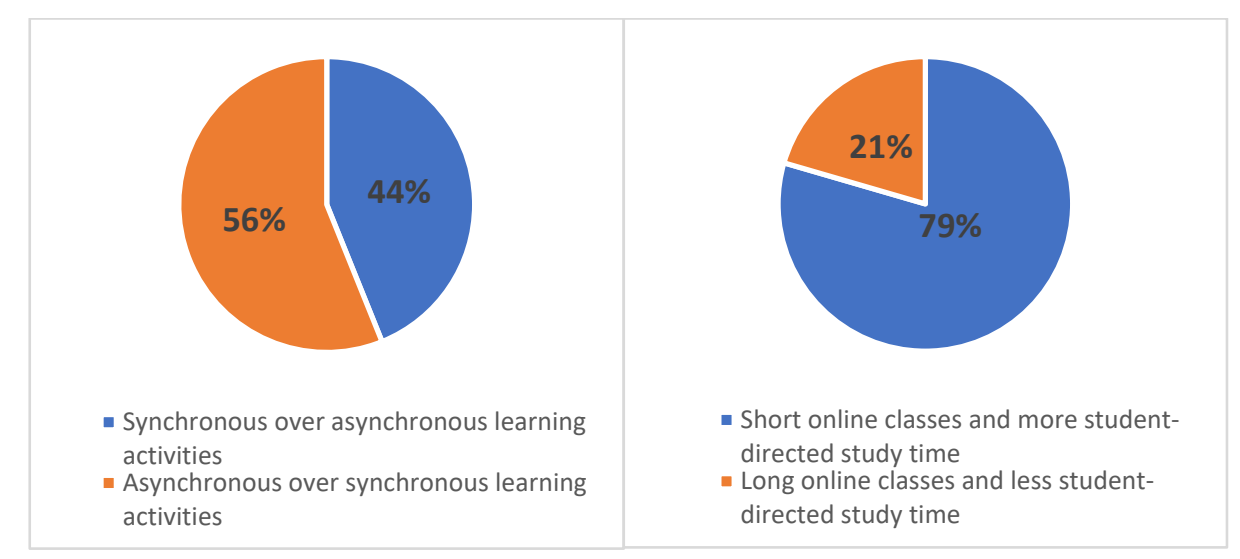

Figure 7: students' preferences regarding the design and delivery of online classes

In the open-ended question, students were asked to think of additional improvements that were not included in the inquiry list. They suggested a variety of additional improvements as listed in Table 7. Student A commented "instead of turning off their cameras, teachers should show us their face", while student B commented "students should be encouraged to engage, and the blame culture should be replaced with encouragement culture".

Table 7: additional improvements suggested by students through the open-ended question

\begin{tabular}{|l|c|}
\hline Improvement suggested through the open-ended question (n=342) & $\begin{array}{c}\text { Frequency of mentioning } \\
\text { each improvement }\end{array}$ \\
\hline Faster and more stable internet connection & 34 \\
\hline Unification of online platforms and apps across different subjects & 30 \\
\hline Improving the design of the online platform, fewer crashes, more user-friendly interface & 28 \\
\hline $\begin{array}{l}\text { Providing recorded lectures in advance and devoting online classes to answering students' } \\
\text { questions }\end{array}$ & 20 \\
\hline Classes that feature more fun and entertainment & 18 \\
\hline More training to enhance digital pedagogy of both teachers and students & 16 \\
\hline Classes that feature simplicity and clarity of expectations, information, and guidelines & 16 \\
\hline
\end{tabular}




\begin{tabular}{|l|c|}
\hline Improvement suggested through the open-ended question (n=342) & $\begin{array}{c}\text { Frequency of mentioning } \\
\text { each improvement }\end{array}$ \\
\hline Shifting from teacher-centred to student-centred classes & 12 \\
\hline More focus on methods to boost students' interest in online classes & 8 \\
\hline Developing a tool to track the learning status of students & 6 \\
\hline The provision of textbooks & 6 \\
\hline
\end{tabular}

\section{Discussion}

\subsection{A reflection on the results}

Online classes during the pandemic brought several benefits that were significantly perceived by the majority of students. They featured a study-life balance plus a certain level of flexibility while allowing students to feel connected to a digital community where they can interact with teachers and other students. At the same time, the majority of students suggested that the design and schedule of online classes should be discussed with them, while activities that enhance the interaction and engagement among students should be implemented. Similar findings are presented by Beldarrain (2006); her study explains that the student of the $21^{\text {st }}$ century demands an educational experience that is not bound by time or space and yet facilitates interaction with teachers and peers.

Almost all students stated that online classes enhanced their familiarity with digital learning technologies. This perceived benefit is also documented in ilin (2019). However, he found that online learning improves the technological knowledge of learners and equips them with skills that are necessary for their future careers. In the present study, this specific benefit was relatively controversial and gained mixed views, was at least half of students either did not agree or was not sure whether practising during online classes made them more confident and prepared for their future career. This finding raises some concerns about the online model and its capability of equipping students with skills that are required for their future careers. This specific point is very relevant in the present study because all responding students belong to the Business English and e-commerce majors and participating in online - and face-to-face - business meetings or negotiation, exhibitions, and trade fairs are very common duties of their future role. These professional activities usually require a certain level of fluency in English as a spoken language plus familiarity with digital devices. To summarise, some issues need to be addressed to guarantee online classes can positively contribute to students' employability and associated required skills.

Academics, teachers, and experts in the higher education field suggested that students might face new pandemic-related challenges that could degrade their experience with online classes. These include mental pressures, worries about their health, financial pressure, worries about the future, being sick, living with a sick family member, and not having adequate study space (Lederman, 2020a; Lederman, 2020b). The present study showed that these challenges were not significant and each of them was perceived by less than $30 \%$ of respondents. In contrast, other non-pandemic related challenges such as time management issues, being distracted by other online activities, and the need for additional study time to adapt to the new learning style were more prominent. Being distracted by social media, surfing the internet, and other online activities during online classes constituted one of the most significant challenges for students. This finding in specific resembles findings of other similar studies in the field. For instance, Karal, Cebi and Turgut (2011) discuss that students tend to merely focus on online lessons in the presence of teachers in real classroom settings, while they tend to be more distracted by other activities in online settings. Finally, the digital divide was not significant in the study and most students had technological devices and used them in online classes. Students showed competency in tackling technological issues and most of them were able to solve such issues.

\subsection{A broader view}

The Covid-19 pandemic has imposed radical changes on higher education around the world and has equally facilitated unprecedented experiences from which lessons can be learned. To keep up with the rapidly changing circumstances and unexpected events, the post-pandemic era should witness comprehensive reforms in education concepts and teaching platforms, methods, and relationships (Lingyun, 2020). Wu Yan, the director of the Higher Education Department of the Ministry of Education in China stated that "we can no longer and should not return to the state of teaching and learning of the pre-pandemic era... after colleges resume, online teaching and learning should become the new normal" (Wu, 2020). He emphasized that after controlling the pandemic, the internet and educational technologies should be integrated into the educational process, while online classes should go in parallel with classroom teaching. The findings of the study correspond to Wu's visions, 
especially when students' answers showed a tendency to prefer a blended model that combines both classroom and online modes in the future.

The sudden shift to online classes meant that students needed additional study time to get accustomed to the new learning style and technology. This was the most significant challenge, and it could be avoided during future emergencies and uncertainties. In the future, universities will reopen their campuses and classroom will again be the dominant model. Findings of the present study encourage that online classes and activities could be systematically and regularly integrated into the curriculum and could accompany classroom lectures. In other words, online classes should not be limited to emergency settings, and measures of the 'emergency time' should be also adopted during 'normal times'. Adopting a 'blended mode' in normal times will; boost students' preparedness for unexpected circumstances during emergencies; enhance students' familiarity with the online learning style; and, allow the online teaching and learning culture to gradually thrive.

\subsection{Improvements and suggestions}

To facilitate the adoption of a sustainable blended model in the post-pandemic era, there should be profound changes in teachers' approaches and methods, students' mentality and skills, and universities' management and policies (Wu, 2020). The following list presents some improvements that respond to findings of the present study and can enhance the preparedness for future pandemics, emergencies, and uncertainties:

- Colleges and universities should be supported by convenient, flexible, and modern digital platforms and close coordination between the government, tech, and digital firms are required in this regard. It is necessary to develop digital teaching and learning platforms that feature personalisation and contextualisation, to suit students of different capabilities and to fit the requirements of different subjects (Ronghuai, 2020).

- Teachers should carefully select a live-streaming app that can fulfil the requirement of the online class. Some apps do not feature an extensive level of communication between students, while others do not have a playback function. For example, for English language learners, it is important to practice speaking and pronunciation skills not only with teachers but also with other students. The currently used apps such as Ding Talk should be upgraded to address academic requirements and to facilitate an enhanced level of student-to-student communication.

- While some classes may require lecturing, others may demand students to collaborate and engage with one another. So, teachers should let their pedagogy inform techniques that suit different pedagogical styles.

- Students could be engaged in designing the class format. In such a time where aspects of life are changing rapidly and unexpectedly, it is essential to give students some authority over learning (Boudreau, 2020).

- During emergencies, students spend most of their time at home with much less opportunity to interact with others. Icebreaking activities and online games are useful in this regard (Lederman, 2020a). So, teachers should design online classes that allow students to engage and socialise with each other.

- Teachers' expectations should be clear and available at the early stages (Boudreau, 2020).

- Concise sessions and brief lessons might be more effective and suitable especially when students are surrounded by many distractions in their homes, and where they might be required to do other household tasks.

- Using online calendars is useful for highlighting dates of classes, meetings, exams, and submission deadlines (Farah, 2020).

- Flexibility is very important during rapidly changing and unexpected circumstances and teachers should be able to swiftly modify or neglect methods and techniques that do not adequately work (Lederman, 2020a).

- $\quad$ Simplicity and clarity are important. In online learning, the teacher is less present to answer questions and queries of students, and the most of learning time is driven by tasks and activities that demand selfdirection (Lederman, 2020b).

- Longer and student-driven assignments are useful for saving classes' time. Also, longer assignments with clear checkpoints buy teachers more time to plan future activities (Farah, 2020).

- A single digital platform where students can access the most recent course information like instructions, deadlines, and tasks is necessary to create stability and make students more comfortable (Boudreau, 2020). 
- Individual touchpoints should not be forgotten, and teachers should be approachable outside online classes.

- To bridge the digital divide, and to ensure that no students are left out, disadvantaged students could be subsidised. Laptop loans or grants could be offered to disadvantaged students and universities could negotiate deals with network providers to offer - discounted or free - data plans (Zhaohui, 2020).

\subsection{Limitations}

Students' responses might be subjective, biased, or influenced by external factors such as their overall satisfaction, wellbeing, or relationship with their instructors. Another limitation is that the questionnaire was administrated to a group of students who belong to the same country, province, institution, academic level, and discipline. In other words, findings might be bound to the selected sample and context and hence cannot be generalised. Also, the digital gap among students in poor provinces might be more evident than the gap between students in rich provinces. Further, the study did not test the reliability or validity of results, and statistical analysis and econometric modelling are required for such a purpose. Future studies could adopt a broader perspective by examining perceptions of students from different countries, universities, disciplines, and academic levels. Finally, future studies could closely research topics of online examination and assessment in pandemic settings, as the present study did not reflect on these aspects.

\section{Conclusion}

The Covid-19 pandemic has radically changed and disrupted education; universities have closed their campuses, and many have shifted to online courses. In the pre-pandemic era, online classes are associated with several benefits and challenges, and the pandemic might have brought additional benefits and obstacles. An online questionnaire was administrated to students of the Business English and Ecommerce majors at the Economics and Trading department of Hunan Railway Professional Technology College in China.

Online classes during the Covid-19 pandemic brought several benefits like creating a digital learning community, improving students' digital learning skills, and staying connected during tough times. Challenges comprised adaptability issues due to the sudden shift to online classes, time-management issues, being distracted by social media plus technological obstacles. Regarding beliefs, students believed that a blended model that combines both classroom and online modes is necessary for the post-pandemic era.

Previous studies looked at the benefits and challenges associated with online classes during regular settings. This study added new findings by looking at benefits and challenges during pandemic settings, by examining students' experience with online classes during the lockdown. The study presented a comprehensive set of potential improvements and allowed students - through open-ended questions - to express their opinions.

Shifting to online classes during the Covid-19 pandemic constituted unprecedented experience and brought priceless lessons from which we should learn. The post-pandemic era will bring new emergencies, pandemics, and uncertainties. A blended model that combines online and face-to-face classes could be adopted to; boost students' preparedness for unexpected circumstances during emergencies; enhance students' familiarity with the online learning style; and, allow the online teaching and learning culture to gradually thrive. Researchers could consider developing digital teaching and learning platforms and apps that feature personalisation and contextualisation, to suit students of different capabilities and to fit the requirements of different subjects. Researchers are encouraged to update the currently-used live-streaming apps and platforms to make them more academic-oriented and in a way that features an extensive level of communication between students. To guarantee a sustainable and adequate online model in the post-pandemic era, improvements are required at different levels.

\section{Acknowledgements}

The author is grateful for the financial support received from the Hunan Social Science Fund Project for The Design and Application Research of Micro-learning for College English, grant number 18WTC25, 2018.

\section{References}

Beldarrain, Y., 2006. Distance education trends: integrating new technologies to foster student interaction and collaboration. Distance Education, 27(2), pp. 139-153.

Bengtsson, M., 2016. How to plan and perform a qualitative study using content analysis. Nursing Plus Open, 2(1), pp. 8-14. 
Berelson, B., 1952. Content analysis in communication research. New York, Free Press.

Boudreau, E., 2020. The shift to online teaching [Online]. Online: Harvard Graduate School of Education. Available at: https://www.gse.harvard.edu/news/uk/20/03/shift-online-teaching [Accessed 16th of April 2020].

Carmichael, F. and Spring, M., 2020. Coronavirus: Here's how you can stop bad information from going viral [Online]. Online: BBC. Available at: https://www.bbc.co.uk/news/blogs-trending-51967889 [Accessed 28th of May 2020]

Easton, M., 2020. Coronavirus: social media 'spreading virus conspiracy theories' [Online]. Online: BBC. Available at: https://www.bbc.co.uk/news/uk-53085640 [Accessed 19th of June 2020].

Elo, S., Kääriäinen, M., Kanste, O., Pölkki, T., Utriainen, K. and Kyngäs, H., 2014. Qualitative content analysis: a focus on trustworthiness. Sage Open, 4(1), pp. 2158244014522633.

Farah, K., 2020. 4 tips for teachers shifting to teaching online [Online]. Online: Edutopia. Available at: https://www.edutopia.org/article/4-tips-supporting-learning-home [Accessed 18th of April 2020].

Fauzi, A., Wandira, R., Sepri, D. and Hafid, A., 2021. Exploring students' acceptance of google classroom during the covid-19 pandemic by using the technology acceptance model in west Sumatera universities. Electronic Journal of e-Learning, 19(4), pp. 233-240.

Gewin, V., 2020. Five tips for moving teaching online as covid-19 takes hold. Nature, 580(7802), pp. 295-296.

Giannoulas, A., Stampoltzis, A., Kounenou, K. and Kalamatianos, A., 2021. How Greek students experienced online education during covid-19 pandemic in order to adjust to a post-lockdown period. Electronic Journal of e-Learning, 19(4), pp. 222-232.

Goodyear, P. and Zenios, M., 2007. Discussion, collaborative knowledge work and epistemic fluency. British Journal Of Educational Studies, 55(4), pp. 351-368.

Hung, M.-L., Chou, C., Chen, C.-H. and Own, Z.-Y., 2010. Learner readiness for online learning: scale development and student perceptions. Computers and Education, 55(3), pp. 1080-1090.

İlin, G., 2019. Sustainability in lifelong learning: learners' perceptions from a Turkish distance language education context. Sustainability, 11(19), pp. 5284.

Itu-News., 2020. Covid-19: how students view the sudden shift to online learning [Online]. Online: ITU News. Available at: https://news.itu.int/covid-19-how-students-view-the-sudden-shift-to-online-learning/ [Accessed 8th of April 2020].

Jack, A. and Smyth, J., 2020. Coronavirus: universities face a harsh lesson [Online]. Online: Financial Times. Available at: https://www.ft.com/content/0ae1c300-7fee-11ea-82f6-150830b3b99a [Accessed 28th of April 2020].

Karal, H., Cebi, A. and Turgut, Y. E., 2011. Perceptions of students who take synchronous courses through video conferencing about distance education. Turkish Online Journal of Educational Technology, 10(4), pp. 276-293.

Kaup, S., Jain, R., Shivalli, S., Pandey, S. and Kaup, S., 2020. Sustaining academics during covid-19 pandemic: the role of online teaching-learning. Indian Journal of Ophthalmology, 68(6), pp. 1220-1221.

Kebritchi, M., Lipschuetz, A. and Santiague, L., 2017. Issues and challenges for teaching successful online courses in higher education: a literature review. Journal of Educational Technology Systems, 46(1), pp. 4-29.

Kumar, S., 2015. 5 common problems faced by students in elearning and how to overcome them [Online]. Online: ELearning Industry. Available at: https://elearningindustry.com/5-common-problems-faced-by-students-in-elearningovercome [Accessed 15th of April 2020].

Langer-Crame, M., Killen, C., Newman, T., Beetham, H. and Knight, . S., 2019. Digital experience insights survey 2019: findings from students in UK further and higher education [Online]. Bristol: JISC. Available at: https://www.jisc.ac.uk/reports/digital-experience-insights-survey-2019-students-uk [Accessed 4th of November 2021].

Lederman, D., 2020a. The shift to remote learning: the human element [Online]. Online: Inside Higher ED. Available at: https://www.insidehighered.com/digital-learning/article/2020/03/25/how-shift-remote-learning-might-affectstudents-instructors-and [Accessed 28th of April 2020].

Lederman, D., 2020b. Will shift to remote teaching be boon or bane for online learning? [Online]. Online: Inside Higher ED. Availableat : https://www.insidehighered.com/digital-learning/article/2020/03/18/most-teaching-going-remote-willhelp-or-hurt-online-learning [Accessed 29th of April 2020].

Lin, B. and Hsieh, C.-T., 2001. Web-based teaching and learner control: a research review. Computers and Education, 37(34), pp. 377-386.

Lin, Y. and Nguyen, H., 2021. International students' perspectives on e-learning during covid-19 in higher education in australia: a study of an Asian student. Electronic Journal of e-Learning, 19(4), pp. 241-251.

Lingyun, Z., 2020. How to change the teaching methods of higher education in the post-epidemic era? Listen to what the big guys say. [Online]. Chutian Metropolis Daily. Available at: https://baijiahao.baidu.com/s?id=1668848999893297775\&wfr=spider\&for=pc [Accessed 2nd of June 2020].

Luyt, I., 2013. Bridging spaces: cross-cultural perspectives on promoting positive online learning experiences. Journal of Educational Technology Systems, 42(1), pp. 3-20.

Lyons, J. F., 2004. Teaching US history online: problems and prospects. The History Teacher, 37(4), pp. 447-456.

Migocka-Patrzałek, M., Dubińska-Magiera, M., Krysiński, D. and Nowicki, S., 2021. The attitude of the academic community towards distance learning: a lesson from a national lockdown. Electronic Journal of e-Learning, 19(4), pp. 262-281.

Ministryof Education., 2020. Introduce the relevant situation of online education in primary and secondary schools during the epidemic and the consideration of the next step [Online]. Online: Ministry of Education of China. Available at: http://www.moe.gov.cn/fbh/live/2020/51987/mtbd/202005/t20200518 455656.html [Accessed 27th of May 2020]. 
OECD, 2018a. ICT familiarity questionnaire for pisa 2018 [Online]. Paris: Organisation for Economic Cooperation and Development. Available at: https://www.oecd.org/pisa/data/2018database/ [Accessed 4th of November 2021].

OECD, 2018b. Student questionnaire for pisa 2018 [Online]. Paris: Organisation for Economic Cooperation and Development. Available: https://www.oecd.org/pisa/data/2018database/ [Accessed 4th of November 2021].

OECD, 2018c. Well-being questionnaire for pisa 2018 [Online]. Paris: Organisation for Economic Cooperation and Development. Available: https://www.oecd.org/pisa/data/2018database/ [Accessed 4th of November 2021].

Pandika, M., 2016. The unexpected effects of all that screen time [Online]. Online: Rally Health. Available at: https://www.rallyhealth.com/health/unexpected-effects-screen-time [Accessed 15th of April 2020].

Parks-Stamm, E. J., Zafonte, M. and Palenque, S. M., 2017. The effects of instructor participation and class size on student participation in an online class discussion forum. British Journal of Educational Technology, 48(6), pp. 1250-1259.

QS, 2020. The impact of the coronavirus on global higher education [Online]. London: QS University Ranking. Available at: https://info.qs.com/rs/335-VIN-535/images/The-Impact-of-the-Coronavirus-on-Global-Higher-Education.pdf [Accessed 4th of November 2021].

Reidy, T., 2020. How to study at home during coronavirus - by online students and tutors [Online]. Online: The Guardian. Available at: https://www.theguardian.com/education/2020/mar/26/how-to-study-at-home-during-coronavirus-byonline-students-and-tutors [Accessed 4th of April 2020].

Richards, L. and Morse, J., 2019. Readme first for a user's guide to qualitative methods, London, Sage Publications Limited.

Ronghuai, H., 2020. How to change the teaching methods of higher education in the post-epidemic era? Hear what the big coffee said [Online]. Online: Chutian Metropolis Daily. Available at: https://baijiahao.baidu.com/s?id=1668848999893297775\&wfr=spider\&for=pc [Accessed 2nd of June 2020].

Rost, M., 2019. A dive into the challenges of online distance learning [Online]. Online: Pearson English. Available at: https://www.english.com/blog/a-dive-into-the-challenges-of-online-distance-learning/ [Accessed 17th of March 2020].

Sahu, P., 2020. Closure of universities due to coronavirus disease 2019 (covid-19): impact on education and mental health of students and academic staff. Cureus, 12(4), pp. 7541-7541.

Silverman, D., 2019. Interpreting qualitative data-sixth edition, London, Sage Publications Limited.

Song, L., Singleton, E. S., Hill, J. R. and Koh, M. H., 2004. Improving online learning: student perceptions of useful and challenging characteristics. The Internet and Higher Education, 7(1), pp. 59-70.

Tam, G. and Elazar, D., 2020. 3 ways the coronavirus pandemic could reshape education [Online]. Online: World Economic Forum. Available at: https://www.weforum.org/agenda/2020/03/3-ways-coronavirus-is-reshaping-education-andwhat-changes-might-be-here-to-stay [Accessed 4th of April 2020].

Tsai, M.-J. and Tsai, C.-C., 2003. Information searching strategies in web-based science learning: the role of internet selfefficacy. Innovations In Education And Teaching International, 40(1), pp. 43-50.

UNESCO, 2020. Education: from disruption to recovery [Online]. Online: United Nations Educational, Scientific and Cultural Organization. Available at: https://en.unesco.org/covid19/educationresponse [Accessed 10th of June 2020 2020].

United Nations., 2020. The covid-19 crisis: accentuating the need to bridge digital divides [Online]. Geneva: United Nations Conference on Trade and Development. Available at: https://www.oecd.org/newsroom/covid-19-crisis-accentuatingthe-need-to-bridge-digital-divides.htm [Accessed 4th of November 2021].

Versta, 2011. How to estimate the length of a survey [Online]. Online: Versta Research. Available at: https://verstaresearch.com/newsletters/how-to-estimate-the-length-of-a-survey/ [Accessed 15th of April 2020].

Vonderwell, S. and Zachariah, S., 2005. Factors that influence participation in online learning. Journal of Research on Technology in Education, 38(2), pp. 213-230.

Wang, L.-C. C. and Beasley, W., 2002. Effects of learner control and hypermedia preference on cyber-students performance in a Web-based learning environment. Journal of Educational Multimedia and Hypermedia, 11(1), pp. 71-91.

Wise, A. F., Speer, J., Marbouti, F. and Hsiao, Y.-T., 2013. Broadening the notion of participation in online discussions: examining patterns in learners' online listening behaviors. Instructional Science, 41(2), pp. 323-343.

Worth, D., 2020. Coronavirus: how to maximise distance learning-with schools closed, teachers are getting to grips with remote learning - what does research say about best practice? [Online]. Online: TES Global. Available at: https://www.tes.com/magazine/article/coronavirus-how-maximise-distance-learning [Accessed 22th of April 2020].

Wu, Y., 2020. Ministry of Education: after the resumption of classes, online courses may become the "new normal"! what do you think? [Online]. Online: China Youth Daily. Available at: https://m.sohu.com/a/395530187 120209891 [Accessed 1st of June 2020].

Xinhua, 2020. Chinese universities to remain closed until effective control of epidemic [Online]. Online: Xinhua Net. Available at: $\mathrm{http}: / /$ www.xinhuanet.com/english/2020-02/25/c 138814715.htm [Accessed 27th of April 2020].

Zaremba, J., 2019. 9 downsides of teaching english online that no one talks about [Online]. Online: Go Abroad. Available at: https://www.goabroad.com/articles/teach-abroad/downsides-teaching-english-online [Accessed 18th of April 2020].

Zhaohui, W., 2020. How a top chinese university is responding to coronavirus [Online]. Online: World Economic Forum. Available at: https://www.weforum.org/agenda/2020/03/coronavirus-china-the-challenges-of-online-learning-foruniversities/ [Accessed 11th of April 2020]. 